\title{
EL DEVENIR PEDAGÓGICO DE LOS SEMINARIOS CONCILIARES ESPAÑOLES EN LA EDAD CONTEMPORÁNEA
}

\author{
POR \\ BEATRIZ COMELLA GUTIÉRREZ \\ Universidad Nacional de Educación a Distancia (UNED)
}

\section{RESUMEN}

El artículo aborda una síntesis sobre la evolución pedagógica los seminarios conciliares españoles partiendo de la llustración; la legislación de los gobiernos españoles y los acuerdos Iglesia Estado sobre los mismos; además expone concisamente la naturaleza y pedagogía de estos centros académicos en los documentos pontificios y conciliares del siglo XX.

PALABRAS CLAVE:

Seminarios conciliares; pedagogía; legislación educativa; acuerdos Iglesia-Estado; documentos pontificios y conciliares del siglo XX.

\section{PEDAGOGICAL BECOMING IN SPANISH CONCILAR SEMINARS DURING CONTEMPORANY AGE}

\section{ABSTRACT:}

This article is about pedagogical evolution in Spanish conciliar seminars starting in Enlightenment until XX century. Also Studies the Spanish Government laws and bilateral Agreements between Church and State; also exposes concisely pedagogy becoming in these academic institutions in papal and conciliar documents during Contemporany Age.

KEY WORDS:

Conciliar seminars; pedagogy; education laws; Agreements between Church and State; papal documents; XX century. 
$\begin{array}{ll}\text { Recibido/Received } & 24-05-2013 \\ \text { Aceptado/Accepted } & 18-03-2014\end{array}$

\section{PRECEDENTES: DE TRENTO A CARLOS III}

Desde su creación en el Concilio de Trento, mediante el canon 18 de la sesión XXIII el 15 julio 1563, los seminarios conciliares estaban destinados a ser centros vinculados a los obispos para la formación de los candidatos al sacerdocio. Solo existe una institución previa en España: un Colegio Mayor para la formación de sacerdotes fundado en 1550 por el arzobispo de Valencia santo Tomás de Villanueva. ${ }^{1}$ Sin embargo, en nuestro país, coincidiendo con el auge de las universidades y las instituciones académicas vinculadas al clero regular, los seminarios o colegios episcopales crecieron escasamente en número y sus enseñanzas se centraron especialmente en la teología moral, ya que el resto de la formación académica se podía recibir en la universidad. ${ }^{2}$ De hecho, hasta 1591 no se fundó en Ávila el primer seminario conciliar y durante el reinado de Felipe II su número solo alcanzó la veintena. ${ }^{3}$

Austrias y Borbones, sus católicas majestades ejercieron, cada uno a su estilo, una tendencia a controlar a los clérigos y a mantener la vieja aspiración de la alianza entre el trono y el altar, iniciada en remotos tiempos por el emperador Constantino, consiguiendo de la Santa Sede los privilegios necesarios para ejercer lo que entendían como necesidad

1 Martínez Herrer, C. 2014. "Santo Tomás de Villanueva O.S.A. y los Colegios jesuitas de Gandía y Valencia. Cuestiones histórico-educativas" Actas del VII Congreso Internacional Educación Católica para el siglo XXI: Universidad Católica san Vicente mártir de Valencia: 287.

2 Vergara Ciordia, J. 1987. "El regalismo jansenista, los obispos ilustrados y San Carlos Borromeo, factores del desarrollo y la configuración de los seminarios en el siglo XVIII" Revista Española de Pedagogía 176: 239-252: Algunas obras clásicas sobre los seminarios conciliares en España son: Sánchez Aliseda, C. 1942. La doctrina de la Iglesia sobre los seminarios desde Trento hasta nuestros días: Granada: Imprenta H. de Paulino; Fernández Conde, M. 1948. España y los seminarios tridentinos: Instituto "Enrique Florez" CSIC: Madrid; Ventura Martín Hernández, F. 1964. Los seminarios españoles. Historia y Pedagogía (1563-1700) Salamanca: Sígueme y 1973. Los seminarios españoles en la época de la Ilustración. Ensayo de una pedagogía eclesiástica en el siglo XVIII Madrid: CSIC.

${ }^{3}$ Vergara Ciordia, J. 2004. Historia y pedagogía del seminario conciliar en Hispanoamérica (1563-1800): Madrid: Dykynson: 61. Antes del seminario conciliar de Ávila se fundó san Juan de Ribera promovió en Valencia el Colegio del Corpus Christi para estudios sacerdotales en 1583. 
de ayudar a la Iglesia en España a cumplir su misión en el plano temporal. ${ }^{4}$

Bien es cierto que ya en los siglos XVI y XVII, en España triunfó la educación vinculada a lo religioso sobre la relacionada con instituciones seglares por tres motivos: el peligro y rechazo al protestantismo, la actividad de la Compañía de Jesús y la sintonía de la jerarquía eclesiástica con los monarcas. ${ }^{5}$

La Casa de Austria se procuró de la Santa Sede un privilegiado Patronato regio sobre los territorios americanos en 1493 y el Consejo de Castilla se ocupaba de revisar los documentos pontificios antes de darles publicidad: el denominado exequatur o pase regio. Los Borbones, a partir del Concordato de 1753, obtuvieron las mismas prerrogativas sobre casi la totalidad de los nombramientos eclesiásticos en España y, en su línea regalista habitual, Carlos III prohibió mediante dos pragmáticas de 1762 y 1768, difundir los documentos llegados de Roma sin examen previo y permiso estatal. ${ }^{6}$

\section{CARLOS III: ECLOSIÓN DE SEMINARIOS, REGALISMO Y JANSENISMO ADMINISTRATIVO}

Sin embargo, con este monarca, a mitad del siglo XVIII, se inició una segunda etapa para los seminarios conciliares en nuestro país: se produce una gran eclosión de ateneos para futuros presbíteros entre 1768 y 1824, que se van desvinculando progresivamente de los ordinarios del lugar, para pasar a formar parte del característico regalismo del despotismo ilustrado hispano. Como en otras naciones europeas, el rey se convirtió en garante de la organización eclesiástica, a costa evidentemente de uncir la Iglesia al carro del Estado. Se intentaba, por todos los medios, teorizar sobre la autonomía del poder regio frente al espiritual eclesiástico, sin llegar a los extremos de la iglesia galicana francesa o la de países protestantes. ${ }^{7}$ El climax de esta coyuntura se produjo con la Real Cédula del 14 de agosto de 1768 por la que los seminarios conciliares se convertían en plataforma óptima para la

4 Greyerz, K. von. 2000: Religion und Kultur. Europa 1500-1800: Göttingen:Vandenhoeck und Ruprecht Verlag.

${ }_{5}^{5}$ Gil Fernández, L. 1997. Panorama social del humanismo español: 435457 Madrid: Tecnos.

${ }^{6}$ Martínez Ruiz, E. 1998. Diccionario de Historia Moderna de España: 208 Madrid: Akal. Una biografía moderna del rey es la de Palacio Atard, V. 2006. Carlos III, el rey de los ilustrados: Madrid: Ariel: 302.

7 Vergara Ciordia, J. (ed.) 1997. Estudios sobre la secularización docente en España: 15 Madrid: UNED y del mismo autor 1987, el citado artículo de la Revista Española de Pedagogía 176: 239-252. 
formación clerical según las ideas del regalismo y el despotismo ilustrado. El poder político se ocuparía del gobierno interior de estos centros, aprobación de sus constituciones y elección de sus rectores o directores a partir de una terna presentada por el obispo. Esta última disposición quedó sin efecto por Resolución del 6 de octubre de 1779, devolviendo ese derecho a los prelados. ${ }^{8}$ Además, el rey aprobó los nuevos planes de estudios de las universidades de Sevilla (1769), Salamanca (1771), Granada (1776) y Valencia (1786); todas ellas dotadas de facultades de teología. ${ }^{9}$

No se abordarán en estas líneas el protagonismo del monarca Carlos III en la expulsión y posterior extinción de los jesuitas, ya que excede el argumento de las mismas y además no pertenecían al clero secular: baste recordar que por Real Cédula de 12 de agosto de 1768 se suprimen las cátedras universitarias de los seguidores de san Ignacio, prohibiendo la utilización de sus textos, a la vez que progresivamente sus edificios y bibliotecas pasaban a manos de otras entidades de enseñanza superior universitaria o episcopal. Parece claro que fue otra manifestación muy acusada de regalismo hispano, a la que solo se opusieron ocho prelados. ${ }^{10}$

Sin embargo, vale la pena recordar que influyó notablemente en ambos hechos, el jansenismo jurídico (distinto del doctrinal) de un grupo de prelados españoles, deseosos de alejar de la nación española los sentimientos ultramontanos y la adhesión a Roma, propios de la orden jesuita. Fue una especie de "herejía administrativa» a la que se unieron sin paliativos, por sus afanes reformistas, los obispos de Barcelona, Salamanca, Pamplona y Sigüenza. ${ }^{11}$ Ese mismo jansenismo jurídico o administrativo fortaleció notablemente cierta idea de una iglesia nacional: aunque el resto de los prelados no la postularon ni la apoyaron, no tuvieron más remedio que acatarla. El jansenismo jurídico 0 administrativo hunde sus raíces en el propio derecho de regalía, de rancias raíces históricas en España, pero de aplicación muy acusada en la segunda mitad del siglo XVIII. Bajo la Casa de Austria, la Santa Sede proporciona a la monarquía hispana cesiones, delegaciones y privilegios a petición de los propios monarcas. Con los Borbones, en la práctica se consideran esos derechos como algo inherente a la corona. Es más, conocidos ilustrados, influidos por la filosofía política francesa especialmente, como Solís, Macanaz, Azara, Camponanes,

8 Vergara Ciordia, J. 1997: 68 y 77.

9 Capitán Díaz, A. 1991. Historia de la Educación: vol I. De los orígenes al Reglamento General de Instrucción Pública: 852-853.

10 García Castro, M. D.-Mediano Benito, J.M. 1998: "La legislación universitaria en España y América durante los primeros borbones": Revista de Estudios de historia social y económica de América: 192-195.

11 Vergara Ciordia, J. 1987: 245. 
Floridablanca, Godoy, etc. llegaron a considerar al rey como vicario de Cristo en asuntos temporales, intentando vaciar de poder ejecutivo a la Iglesia en España. En esta línea está el famoso Pedimento de los 55 puntos, documento privado dirigido a Felipe $\mathrm{V}$ en 1713 por Melchor de Macanaz, Fiscal del Consejo de Castilla, que llegó a oídos de la Inquisición: "Propone el Fiscal General que si pareciese al Consejo se proponga a su Majestad cuan del servicio de Dios y suyo, y de la quietud pública de sus Reynos y vasallos, será declarar que de aquí en adelante ninguno de sus súbditos se valga ni pueda valer de la autoridad de las expresadas Bulas Breves y motu proprios, cánones, Concilios en otras cosas que tocan a la pureza de nuestra santa fe y religión". ${ }^{12}$ La actitud de la jerarquía fue, salvo contadas excepciones, de acatamiento y silencio ante el poder regio. ${ }^{13}$

Las ideas del también ilustrado Carlos III para secularizar los ambientes culturales españoles eran claras y pasaban por reorganizar las universidades de modo centralizado, incluyendo en ellas los estudios eclesiásticos y reformar los seminarios como centros públicos de enseñanza, abiertos a un currículum más amplio, que incluía materias novedosas (matemáticas, física, historia natural, astronomía y otras disciplinas semejantes), siempre sujetos a la autoridad del monarca, por el acatamiento de sus alumnos a las regalías. También propició una vuelta a lo esencial de la filosofía y teología, siguiendo la Sagrada Escritura, los Padres de la Iglesia, los concilios generales y nacionales, a Tomás de Aquino, dejando de lado las eternas disputas entre escuelas minoritarias, basadas en las leyes de la Lógica. ${ }^{14} \mathrm{Ya}$ antes de que el heredero de Felipe V Ilegara a su patria, algunas voces que pasaron a la historia habían advertido estos abusos. Fray Benito Jerónimo Feijoo, una de las voces ilustradas de la Iglesia en España dejó por escrito: "que cuanto dijere en los Discursos que se siguen, no quiero que tenga otra fuerza, o carácter, que el de humilde representación hecha a todos los Sabios de las Religiones, y Universidades de nuestra España. No se me considere como un atrevido Ciudadano de la República Literaria, que satisfecho de las propias fuerzas, y usando de ellas, quiere formar su gobierno; sino como un individuo celoso, que ante los legítimos Ministros

12 Macanaz, M. de, 1841. Pedimento del fiscal general Don Melchor de Macanaz sobre abusos de la Dataría; provisión de beneficios; pensiones; coadjutorias; dispensas matrimoniales, espolios i vacantes; sobre el Nuncio; derechos de los Tribunales eclesiásticos; juicios posesorios y otros asuntos gravísimos. Imprenta Nacional. La Coruña: 47-48.

${ }^{13}$ Vergara Ciordia, J. 1997: "La actitud de la jerarquía eclesiástica ante el fenómeno de la secularización docente ilustrada" 61-95 en Vergara Ciordia, J. (ed.), 1997.

${ }^{14}$ Vergara Ciordia, J. 1987: 242-243. Los tratados que recogían las leyes de la Lógica para su estudio se denominaban súmulas. 
de la Enseñanza Pública, comparece a proponer lo que le parece más conveniente, con el ánimo de rendirse en todo y por todo a su autoridad, $y$ juicio. No hay duda en que el particular, que violentamente pretende alterar la forma establecida de gobierno, incurre la infamia de sedicioso. Pero asimismo, el Magistrado que cierra los oídos a cualquiera que con el respeto debido quiere representarle algunos inconvenientes, que tiene la forma establecida, merece la nota de tirano. Mayormente, cuando el que hace la representación no aspira a la abrogación de leyes, sí solo a la reforma de algunos abusos, que no autoriza ley alguna, y sólo tienen a su favor la tolerancia. Pero en varias conversaciones, en que he tocado este punto, he visto, que no pocos seguían mi opinión, o por hacerles fuerza mis razones, o por tenerlas previstas de ante mano. Así con la bien fundada esperanza de hallar muchos, que leyendo este Escrito, apoyen mi dictamen, propondré en él las alteraciones, que juzgo convenientes en el ministerio de la Enseñanza Pública". ${ }^{15}$ Feijoo se adelantó con sus escritos medio siglo a las propuestas carolinas.

Carlos III secularizó los seminarios conciliares en el sentido de que pretendía que un futuro presbítero tuviera, además de la formación sacerdotal, la propia de un laico ilustrado de su época. El monarca, ferviente católico, no deseaba obviamente establecer un laicismo al estilo de los siglos XIX o XX, sino que estaba convencido de que si el clero era ilustrado, España lo sería también. ${ }^{16}$ En esta línea, el Consejo de Castilla aprobó asimismo el 22 de marzo de 1773 que en las ciudades dotadas de seminario conciliar, pero no de colegios mayores o universidad, los primeros sirvieran como centros públicos de enseñanza. Durante el reinado de Carlos III se produjo esa citada eclosión y renovación de los seminarios: se crearon 11 , que se añadieron a los 28 que ya existían. ${ }^{17}$

\section{LA RELIGIÓN Y LA IGLESIA CATÓLICA EN LOS DOCUMENTOS CIVILES ESPAÑOLES DE LOS SIGLOS XIX Y XX}

En las siguientes líneas nos proponemos revisar los principales documentos civiles vigentes en España durante los siglos XIX y XX (Constituciones y Concordatos) para rastrear en ellos las alusiones y tratamiento que realizan sobre los seminarios conciliares. Es lógico que los gobernantes y la clase política se replantearan las relaciones con la Iglesia en España después de la llustración. Feijoo, Sarmiento, Jovellanos y Quintana habían preparado el terreno. ${ }^{18}$ Entre los clérigos

${ }^{15}$ Feijoo, B. J. 1736. Teatro crítico universal. Discurso 11. Introducción. Publicado por Proyecto de Filosofía en español: www.filosofia.org.

${ }^{16}$ Vergara Ciordia, J. 1987: 239-252.

17 Vergara Ciordia, J. (ed.), $1997: 78$.

18 Redondo, E.-Vergara, J. 1993. "La secularización docente (17761845)" Perspectiva Educacional 21-22: 17-25. 
estaban los futuros párrocos, canónigos y prelados cuya relación e influencia sobre el resto de la población era, a todas luces, notable.

Sin embargo, tanto sacerdotes como miembros de órdenes religiosas, el conjunto de clero español, solo constituyeron una minoría (aproximadamente el $2 \%$ de la población) según el Catastro de Ensenada, ordenado por Fernando VI en 1749. ${ }^{19}$ Esa minoría y sobre todo sus propiedades y capacidad docente fue un objetivo constante, en sentido negativo para la Iglesia, de diversos gobiernos: desde Godoy, José Bonaparte, Mendizábal, Madoz, hasta la II República. ${ }^{20}$

Son varias las fechas decisivas para comprender el destino de los seminarios conciliares españoles, fruto de las ideas antagónicas del siglo XIX español: alternancia de etapas absolutistas, con otras de marcado talante liberal o bien anticlerical. Todas consiguieron un fin semejante, que no fue otro que instrumentalizar o utilizar la educación en pro de las diversas y sucesivas causas políticas, con distintos grados de libertad para la Iglesia católica $y$, posteriormente, para otras confesiones religiosas. Obviamente, es necesario distinguir una lógica evolución hacia la libertad religiosa en España, de una persecución frontal e injusta de los integrantes de la confesión católica (o de cualquier otra evidentemente) por inveterados y viscerales prejuicios.

Durante los siglos XIX y XX España ha tenido diez Constituciones $(1808,1812,1834,1837,1845,1856,1869,1876$ y 1978) y firmado tres Concordatos con la Santa Sede (1851, 1953 y 1979). Por lo que se refiere a las Cartas Magnas, ninguna de ellas cita el término seminario conciliar, pero en todas ellas aparece la postura política del momento ante la Iglesia. El Estatuto de Bayona (vigente entre 1808-1813) considera la religión católica como la oficial y excluye otras. Sin embargo, la de Cádiz de 1812, es la que posee el talante más confesional de todas (supone que la religión católica será perpetuamente la religión de los españoles). En ella, como es sabido, participaron algunos renombrados eclesiásticos y aparece en el título IX una alusión a un plan general uniforme para toda la monarquía para universidades, establecimientos literarios y otros donde se enseñen ciencias eclesiásticas. Desde esta Constitución se considera que la educación es un asunto estatal, aunque

19 El original del Catastro que estudió 150.000 poblaciones de "las Castillas" se encuentra en el Archivo General de Simancas. Dirección General de Rentas ES. 4761. AGS1.14. Una copia no completa compulsada en el Archivo Histórico Nacional AHN. Consejo de Hacienda ES.28079.AHN/1.8. Esta información se ha localizado a través del portal electrónico PARES (Portal de Archivos Españoles).

20 Tomás y Valiente, F. 1989. "El marco político de la desamortización: Madrid: Ariel y Puelles Benítez de, M. 1991 "El sistema educativo republicano: un proyecto frustrado" Historia Contemporánea 6: 159-171. 
a lo largo de políticamente turbulento siglo XIX, la instrucción de carácter privado será permitida de modo habitual. En el Estatuto real (1834-1836) no hay referencia a la religión católica a pesar de su talante conservador.

Durante la minoría de edad de Isabel II se aprobó la Constitución de 1837, firmada por el progresista ministro Calatrava, se indica en el título I artículo 11 que la nación se obliga a mantener el culto y a los ministros de la religión católica que profesan los españoles y se alude a la permisividad, sin referencia directa a la libertad religiosa. En el título IV artículo 23 se concreta que los diputados deben ser seglares. Ramón María de Narváez, como presidente del consejo de ministros firmó la moderada Constitución de 1845 en la que no varía el artículo I, pero se añade en el título III la posibilidad de que el monarca nombre, a título vitalicio a obispos y arzobispos como senadores. La Carta Magna de 1856, llamada nonnata porque no llegó a proclamarse, poseía carácter progresista y avalaba la tolerancia religiosa; algunas de sus bases fueron desarrolladas en la de 1869. En ella, aprobada en pleno Sexenio revolucionario o democrático: según su artículo 21 , aunque la nación sigue manteniendo el culto y a los ministros de la religión católica, se permiten otros cultos para ciudadanos extranjeros o españoles. En el artículo 24 se autoriza a cualquier español a fundar y mantener establecimientos educativos, con tal de que cumplan con las normas de sanidad. Al tornar Alfonso XII a España, los padres de la Constitución de 1876 y su gran aval Cánovas del Castillo, en el artículo 11 se refieren a la religión católica como la oficial, de la que se permitirán manifestaciones públicas, aunque nadie será molestado si profesa otra religión.

Sin duda, la Constitución fechada el 9 de diciembre de 1931 y firmada por Julián Besteiro, fue la que produjo mayor ruptura teórica contra la realidad sociológica de los españoles de entonces, que se consideraban mayoritariamente católicos. Los artículos más conflictivos fueron los siguientes: el 14, por el que se atribuye al Estado de modo unilateral la relación con las iglesias y régimen de cultos; el 26, todas las confesiones religiosas serán consideradas sometidas a una ley especial y no recibirán subsidios estatales, puesto que en dos años se prevé la supresión del presupuesto del clero y, además, la disolución de la Compañía de Jesús, cuyos bienes serían nacionalizados; el 27, por el que el culto católico solo podría ejercerse dentro de las iglesias; el 48 por la enseñanza será laica, aunque permite que los colegios religiosos puedan enseñar su doctrina dentro de sus establecimientos, pero bajo inspección estatal. ${ }^{21}$

${ }^{21}$ Payne, S.G. 1984. Spanish Catholicism: An Historical Overview, Madison: University of Wisconsin Press. 
En la vigente Constitución de 1978, existe separación entre Iglesia y Estado y reconocimiento de la libertad religiosa, aunque se mantienen unas relaciones preferentes con la confesión católica mayoritaria. ${ }^{22}$

Por lo que se refiere a los tres últimos Concordatos, el firmado entre Pío IX e Isabel II el 16 de mayo de 1851 ratifica, en favor de la Iglesia en España el ventajoso acuerdo de 1753 sobre los nombramientos episcopales; en relación a los seminarios conciliares, en el artículo 2 se afirma que la instrucción llevada a cabo en universidades y cualquier establecimiento de enseñanza público, además de los seminarios será en todo conforme a la doctrina católica. El artículo 3 protege a los prelados y ministros sagrados en el ejercicios de sus cargos y se les encarga de la censura previa de libros. La creación sin demora de nuevos seminarios de acuerdo con la nueva distribución diocesana aprobada en este Concordato es el argumento del artículo 28 y, en el 35 les asigna entre 90.000 y 120.000 reales de renta según sus necesidades. Recogemos un significativo fragmento: fue firmado el 16 de marzo 1851 entre Pío IX y el Presidente del Consejo de Ministros de Isabel II, el moderado Juan Bravo Murillo, acompañado de D. Manuel Bertrán de Lis, Caballero de la Orden de Carlos III. Su artículo 28 dice: «el Gobierno de S.M. católica, sin perjuicio de establecer oportunamente, previo acuerdo con la Santa Sede, y tan pronto como las circunstancias lo permitan, seminarios generales en que se dé la extensión conveniente a los estudios eclesiásticos, adoptará por su parte las disposiciones oportunas que se creen sin demora seminarios conciliares en las diócesis donde no se hallen establecidos, a fin de que en lo sucesivo no haya en los dominios españoles iglesia alguna que no tenga al menos un seminario suficiente para la instrucción del clero. Serán admitidos en los seminarios, y educados e instruidos del modo que establece el sagrado concilio de Trento, los jóvenes que los arzobispos y obispos juzguen conveniente recibir, según la necesidad o utilidad de las diócesis; y en todo lo que pertenece al arreglo de los seminarios, a la enseñanza y a la administración de sus bienes, se observarán los decretos del mismo concilio de Trento. Si de resultas de la nueva circunscripción de diócesis quedasen en algunas dos seminarios, uno en la capital actual del obispado y otro en la que se le ha de unir, se conservarán ambos mientras el Gobierno y los prelados de común acuerdo los consideren útiles". Podríamos decir que el Concordato de 1851 es más conservador en relación a los seminarios (vuelta a los postulados tridentinos) que los

${ }^{22}$ Las Constituciones españolas pueden consultarse en la página web http//www.congreso.es.historia/constituciones. Sobre esta cuestión: Laboa Gallego, J.M. 1981: Iglesia y religión en las Constituciones españolas: 45-60 Madrid: Encuentro y Nuñez Rivero, C. 2011: La Iglesia católica y el Estado constitucional. El caso español: Madrid: Endymon S.L. 
de la época de Carlos III, cuando se intenta que triunfen los postulados de la llustración. ${ }^{23}$

Algo más de un siglo después, el general Franco, a través de sus ministros A. Martín Artajo y F. M. Castiella negoció con Pío XII, representado por el Cardenal $\mathrm{D}$. Tardini un amplio Concordato que fue firmado el 27 de agosto de 1953. En el artículo 3 se reconoce el derecho a adquirir bienes por parte de la Iglesia católica; en el 19 se garantizan asignaciones económicas para los seminarios (exentos de impuestos) y universidades católicas. El epígrafe 30 deja claro que tanto los seminarios, como las universidades e institutos superiores eclesiásticos dependen únicamente del ordinario del lugar; sin embargo, cabe recordar que el 8 de diciembre de 1946, ya se había firmado un Convenio entre la Santa Sede y el gobierno de Franco sobre funcionamiento, régimen interno y financiación de los seminarios, que se mantuvo intacto en el Concordato de $1953{ }^{24}$

Iniciada la transición política hacia la democracia, el Estado español firmó el 3 de enero de 1979, a través del ministro M. Oreja Aguirre y el Cardenal Villot un nuevo Acuerdo bilateral, cuyos artículos 8, 9 y 10 no pretenden establecer en absoluto, como en la etapa franquista privilegios hacia la Iglesia católica, sino reconocer sus derechos en materia educativa eclesiástica; los citados epígrafes tratan sobre los seminarios menores y su homologación con los alumnos de la misma edad; la acomodación de los centros eclesiásticos a la legislación educativa general y la posibilidad de establecer estudios teológicos en universidades públicas. ${ }^{25}$

${ }^{23}$ Cárcel Ortí, V. 1981. "Decadencia de los estudios eclesiásticos en la España del siglo XIX" Hispania Sacra 33: 19-32 y 1990 "Estado material, académico y moral de los seminarios españoles durante el siglo XIX" Seminarios 77-78: 267-275.

24 Pérez Mier, L. 1947. "El Convenio español sobre seminarios y universidades de estudios eclesiásticos" Revista Española de Derecho Canónico 2: 87-152. En este Concordato existen muchos epígrafes relacionados con el clero, la financiación eclesiástica y la enseñanza de la religión, etc.

${ }^{25}$ Existen en España referidas a ciertos aspectos del Concordato de 1979, corrientes de opinión de sectores laicistas según los cuales, aunque existe separación Iglesia-Estado según nuestra Carta Magna, las asignaciones financieras a la confesión católica deberían reformarse, aunque la Constitución española reconoce una especial reconocimiento de su papel en la sociedad española. Por otra parte, en los últimos decenios se ha procedido a firmar acuerdos bilaterales entre el Ministerio de Justicia y otras confesiones no católicas. Un estudio científico de esta cuestión Piñero, J.M. 1979. "La dotación de la Iglesia por el Estado en los nuevos acuerdos entre la Santa Sede y España". Ius Canonicum 19:303-328. Desde la perspectiva pedagógica, existe el estudio de García Fraile, J.A. 1996. "La educación en los Textos 


\section{LAS LEYES EDUCATIVAS CIVILES Y SU RELACIÓN CON LOS SEMINARIOS CONCILIARES}

Tras la Constitución de 1812, el sector más liberal de las Cortes encargó al ilustrado y poeta José Manuel Quintana (1772-1857), un Informe (1813) que dio lugar Reglamento General de Instrucción Pública de (29-6-1821), que estuvo en vigor tras el golpe del General Riego y durante el trienio liberal. Las ideas de Quintana son un reflejo del ambiente que se respiraba en la Sociedades del Amigos del País y en las Juntas de Comercio. También se inspiran en las obras de Mayans, Olavide, Jovellanos, Campomanes y Cabarrús, además de las redactadas por el francés Concorcet. Resultan de una peculiar mezcla del liberalismo incipiente español y el contagio de los ideales de la Revolución y postrevolución francesa.

En cuanto a la primera y segunda enseñanza desarrollaba las ideas de igualdad, universalidad y uniformidad de textos para los alumnos varones; las niñas quedaban excluidas y encaminadas a una enseñanza doméstica. En el título $V$ se refiere a la enseñanza que denomina tercera o universitaria y en ella se establece la siguiente breve normativa:

Art. 40. En todas estas universidades se enseñarán la teología y la jurisprudencia civil y canónica, con los estudios auxiliares que son útiles para la enseñanza de estas ciencias o de alguna de ellas.

Art. 41. Estos estudios auxiliares se distribuirán en la forma siguiente:

Lengua hebrea, 1 curso

Lengua griega, 1 curso

Historia literaria y bibliografía, 1 curso

Numismática y antigüedades, 1 curso

Art. 42. La enseñanza de la teología se distribuirá en la forma siguiente:

Constitucionales españoles":148-153 en Berrio, J. (ed.) La educación en España. Textos y documentos: Madrid: Actas. 
Fundamentos de la religión, historia de la teología y lugares teológicos, 1 curso

Instituciones dogmáticas y morales, 3 cursos

\section{Sagrada Escritura, 1 curso}

Liturgia, práctica pastoral y ejercicios de predicación, 2
cursos.

No llama la atención que un gobierno liberal dedique escasas líneas al estudio de le teología ni que se incluyan en los estudios eclesiásticos estudios de Literatura y bibliografía, pero no es de extrañar si el origen del plan de estudios es la pluma de un ilustrado y poeta. Los planes de Quintana tuvieron corta vida al restablecerse el absolutismo entre 1823-1833 de Fernando VII por la intervención de las tropas francesas y la posterior promulgación del Plan literario de estudios y arreglo general de las universidades del Reino (14-10-1824), del Plan y Reglamento de escuelas de primeras letras del Reino (16-2-1825), y del Reglamento general de las escuelas de latinidad $y$ colegios de humanidades (16-1-1826). Estas reformas, que se denominaron Plan de Calomarde (1773-1842), Ministro de Gracia y Justicia, por ser éste el responsable oficial de su elaboración. Parece que el monarca tenía gran interés en que la aplicación del Informe Quintana desapareciera cuanto antes de la legalidad vigente y el ministro convocó en reuniones diarias a un grupo de consejeros jubilados y varones sabios. Los dos más conocidos por su influencia en la legislación bautizada con el nombre del ministro fueron el fraile mercedario Manuel Martínez Ferro y el vicario general de los escolapios, Joaquín Esteve de San Miguel. ${ }^{27}$ Esta reforma significó un claro intento de cambiar lo esbozado por el Trienio liberal para consolidar la instrucción pública como instrumento eficaz del absolutismo; sus características fueron: centralización, reglamentación, jerarquía, inspección y religiosidad. ${ }^{28}$

${ }^{26}$ Capitán Díaz, A. 1991: 895.

${ }^{27}$ El primero nació en Caldas de Reis en 1774 e ingresó en el convento mercedario de Conxo en 1787. Doctor en Teología y catedrático de la Universidad de Valladolid, apoyó la Constitución de 1812. Huyó a La Coruña con la llegada de los franceses y entonces empezó su acercamiento al absolutismo. Fue obispo de Málaga entre 1825-1827. Barreiro, X.R. 2003. Historia de la Universidad de Santiago de Compostela: vol. II El siglo XIX. Publicaciones de la Universidad de Santiago: 46: Santiago de Compostela. Joaquín Esteve de San Miguel nació en Fuentespalda (Teruel); estudió Humanidades en Alcañiz y era un experto latinista. Profesó en los escolapios en 1788. Alonso Marañón, P.M. 1996. La Iglesia docente en el siglo XIX: Publicaciones de la Universidad de Alcalá de Henares: 110: Alcalá de Henares.

28 Ministerio de Educación Cultura y Deporte, 2004: El Sistema Educativo español. Madrid: MECD/CIDE, p. 2. 
La primera ley (Real Orden de 14 de octubre de 1824) mantuvo los estudios de teología solo en cinco universidades dejó sin validez práctica los estudios realizados en los seminarios diocesanos y exigía que los grados académicos de los futuros presbíteros se adquieran en las universidades. A los seminarios se refiere la nueva norma en el título II:

Art. $9^{\circ}$ Los Seminarios conciliares quedan incorporados a las respectivas Universidades, bajo las declaraciones siguientes:

Art. 10. Primera: El plan literario de estudios, las asignaturas de cátedras, matrículas, exámenes, duración del curso, academias, horas y método de enseñanza serán los mismos que en las Universidades, y sólo así gozarán los Seminarios el beneficio de la incorporación.

Art. 11. Segunda: En las tres cátedras de instituciones filosóficas ganarán curso académico los seminaristas, fámulos, pensionistas y los escolares externos que se matricularen y concurrieren a ellas con puntualidad y aprovechamiento.

Art. 12. Tercera: La incorporación de los cuatro años de instituciones teológicas se limita y concede solamente a los seminaristas, a los fámulos y a los pensionistas con beca o sin ella, con tal que vivan en los seminarios y sujetos a su disciplina anterior. Acreditadas en forma estas condiciones, serán admitidos a los grados de bachiller en las Universidades respectivas.

Art. 13. Cuarta: Si en los Seminarios se establecieren las cátedras superiores de enseñanza que por este plan se requieren para los grados de licenciado y doctor, y se confieren a prebendados de oficio $u$ a otros sujetos de acreditado saber, entonces serán admitidos a recibirlos los seminaristas, fámulos y pensionistas que hubieren ganado los tres últimos cursos, según el orden establecido.

Art. 14. El rector o superior de los Seminarios y Colegios remitirán a la Universidad todos los años en el mes de diciembre una lista individual de los jóvenes que se hayan matriculado, y otra en septiembre de los que hubieren ganado curso, acompañando a esta última las notas reservadas que hayan dado los Catedráticos, al tenor de las que se mandan a los de las Universidades.

Esto significó, a todas luces, un nuevo atentado contra la autonomía de la Iglesia en materia educativa o una intrusión del 
absolutismo fernandino, ya que no se respetaban las normas tridentinas vigentes, que hacían responsable a cada obispo de su seminario. No obstante, Calomarde también previó en el artículo 6 del título I que se ayudara económicamente a los seminarios necesitados. ${ }^{29}$ Sobre la evolución de la enseñanza de la lengua latina, que había perdido mucha importancia con la expulsión de los jesuitas, los distintos gobiernos del siglo XIX hay que tener en cuenta «que no se puede estudiar la evolución gramatical en una determinada época, sin tener en cuenta las influencias educativas, culturales y políticas del momento. Las gramáticas son instrumentos de enseñanza y, como tales, dependen metodológicamente de los que dictan esa enseñanza, que suelen ser políticos, a los que conviene una didáctica y pedagogía determinada para sus fines ideológicos, ligados casi siempre a su permanencia en el poder. De esta forma, política, educación y gramática se entrecruzan un conjunto armonioso y no carente de sentido». ${ }^{30}$

Los seminarios de la segunda mitad del siglo XIX españoles pasaron a ser instituciones diocesanas fragmentadas, cada una muy encerrada en sí misma, aferradas a la tradición eclesial; se hallaban como a la defensiva por los daños colaterales que la alternancia de liberalismo y absolutismo habían proporcionado desde el primer tercio de siglo.

Durante el reinado de Isabel II se aprobaron tres leyes educativas; las dos segundas aluden a los estudios eclesiásticos. Durante la Década liberal el Plan General de Instrucción Pública (4-8-1936) del Duque de Rivas ya en la Década moderada y el Plan General de Estudios de Pedro José Pidal (17-9-1845) y en el Bienio progresista, la Ley de Instrucción Pública de Claudio Moyano (9-9-1857). ${ }^{31}$

La ley promovida por Pidal refleja la relación entre universidades y seminarios, según el gobierno. Su artífice afirma en el texto: «No sucede así con la Teología: escasos en extremo son los que acuden a estudiar esta facultad en las Universidades. Las trece que había en España sólo han reunido estos años pasados 350 teólogos, no llegando todavía en el último curso a 400. Algunas hay, y no pocas, en que su número no iguala al de los catedráticos; y Barcelona, después de haber estado con dos o tres, se han quedado sin ninguno. La causa de esto es que los aspirantes al sacerdocio prefieren hacer su carrera en los seminarios conciliares, cuyo número en España pasa de 50, estando asignada para su

29 Suárez, F. 1988. La crisis política del Antiguo Régimen en España (1800-1840): Madrid: Rialp.

30 Espino Martín, J. 2003. "Política y enseñanza del latín: conservadores y liberales en la enseñanza de la gramática latina durante el reinado de Fernando VII". Estudios Clásicos 123: 45-65.

31 Capitán Díaz, A. 1991: 53-97. 
sostenimiento la cantidad de dos millones y medio en el presupuesto general del Estado. Conviniendo, sin embargo, que el estudio de la Teología se conserve en las Universidades, se ha dejado en cinco de ellas, pudiendo hacer en las demás las veces de Facultad el respectivo seminario, siempre que arregle la enseñanza a lo que en el nuevo plan se previene.

Art. 69. El estudio de la Teología podrá hacerse en las Universidades o en los Seminarios conciliares.

Art. 70. Para que los estudios de Teología hechos en los Seminarios conciliares tengan incorporación en las Universidades y puedan adquirir por este medio carácter académico es necesario que en aquellos establecimientos se siga el plan literario con sujeción a las asignaturas, matrículas, exámenes, duración del curso, academias, horas y método de enseñanza establecido para las mismas Universidades.

Art. 71. La incorporación de los estudios de Teología hechos en los Seminarios se limita y concede solamente a los seminaristas, a los fámulos y a los pensionistas con beca o sin ella, con tal que vivan en los Seminarios y sujetos a su disciplina interior.

Art. 72. Tendrán Facultad de Teología las Universidades de Madrid, Oviedo, Sevilla, Valladolid y Zaragoza.

Art. 73. En las demás Universidades de Barcelona, Granada, Salamanca, Santiago y Valencia hará las veces de Facultad de Teología el respectivo Seminario conciliar; y no obstante lo dispuesto en el artículo 71, obtendrán la incorporación de sus estudios todos los que en él cursaren, sean internos o externos.

Art. 74. Para que la incorporación de estos estudios pueda llevarse a efecto, los rectores o superiores de los Seminarios remitirán al rector de la Universidad del distrito las listas individuales de los matriculados y demás noticias que especificará el reglamento". ${ }^{32}$

La Ley Pidal parece un anuncio de lo que sucederá siete años más tarde, a pesar del restablecimiento de las relaciones entre Roma y Madrid en el citado Concordato de 1851. Al año siguiente, Bravo Murillo fue cesado en diciembre de 1852 y el nuevo ministro de Gracia y Justicia, Ventura González Romero impulsó la firma regia del Real Decreto de 21

${ }^{32}$ www.filosofia.org/mfa/e1857ley.htm 
de mayo de 1852 por el que se suprimían las facultades eclesiásticas del ámbito de las universidades civiles. Según el citado documento, los prelados diocesanos debían organizar dichos estudios según creyeran más conveniente. ${ }^{33}$ La nueva política religiosa parecía apuntar a un cambio: la monarquía no pierde privilegios sobre la Iglesia en España, pero se desvincula del intervencionismo carolino sobre los seminarios, que deja en manos de los obispos. Esta realidad puede interpretarse de diversas maneras, pero en principio significó una notable dificultad para los prelados, que debían rehacer una red académica partiendo de escasos medios. ${ }^{34}$

Por su parte, la Ley Moyano, solo dedica un artículo del capítulo primero a los estudios eclesiásticos y se tratan las relaciones entre el Estado y la Iglesia con vaguedad. Se debe tener en cuenta que la ley fue sancionada en pleno bienio progresista y tras la desamortización municipal promovida por Pascual Madoz en 1855. El texto señala: «Art. 46. No se hará novedad por ahora en los estudios de la Teología que hoy se dan en las Universidades. Se reserva el Gobierno la facultad de hacer uso, con respecto a ellos, de la autorización que le concede la ley de 17 de Julio último, cuando se verifique el arreglo definitivo de los mismos estudios en los Seminarios conciliares, 0 antes, si pareciere conveniente». ${ }^{35}$

En las siguientes líneas se resumirán los principales hechos de la historia reciente de la educación en España, para contextualizar su relación con el tema de este artículo. Durante la regencia de María Cristina de Habsburgo (1885-1902) se creó el Ministro de Instrucción Pública y Bellas Artes el 31 de marzo de 1900; su primer titular fue Antonio García Alix. Entre 1882 y 1907 se desarrolló la primera etapa de la Institución Libre de Enseñanza y por Real Decreto (11-1-1907) se creó la Junta de Ampliación de Estudios en el extranjero (JAE). Durante la Dictadura de Primo de Rivera, se aprobó la Reforma del Bachillerato denominado Plan Callejo en 1926 y una mínima reforma apunta hacia la

33 Rodríguez San Pedro, L.E.-Polo Rodríguez. 2010. Universidades hispánicas: colegios y conventos universitarios en la Edad Moderna II: Salamanca: Universidad de Salamanca, p. 117 y Andrés Martín, M. 1976. La supresión de las facultades de teología (1845-1855): Burgos. Aldecoa.

34 García Navarro, J.J. 1992: El origen histórico español de las facultades eclesiásticas y la legislación eclesiástica desde la Constitución Deus Scientiarum Dominus a la Sapientia Christiana: Tesis doctoral inédita, Universidad de Navarra. El enfoque de este trabajo se centra en las facultades de Derecho Canónico.

35 www.filosofia.org/mfa/e1857ley.htm. Únicamente hemos hallado los textos completos de las leyes educativas del siglo XIX en esta página web, aunque existen manuscritos en la Biblioteca Nacional, sin datos editoriales, solo con descripción externa. 
autonomía universitaria en 1928. El Centro de Estudios Universitarios (CEU), promovido por los Propagandistas se fundó en 1933.

Durante la etapa franquista, se aprobó la Ley de Bachillerato (1938) y la de Educación Primaria (1945) que seguían la inspiración de la Encíclica de Pío XI Divini illius Magistri (31-12-1939) y las ideas del nacional catolicismo. ${ }^{36}$

Tras la Guerra Civil, las tareas de la JAE fueron asumidas por el CSIC, creado el 24 de noviembre de 1939. Al año siguiente se establece el Consejo Nacional de Educación (13-8-1940); muchos de sus miembros eran afectos a la FET y a las JONS, a la jerarquía eclesiástica y a grupos católicos. La primera ley universitaria posterior a la Guerra fue la Ley de Ordenación Universitaria (LOU) de 1943. A partir del ministerio de Ruiz Giménez (1951-1956) se inicia una etapa de aperturismo que culmina con el denominado Libro blanco de la Educación y la Ley General de Educación (LGE) del ministro Villar Palasí de 1970.

Las leyes educativas posteriores a la firma de la Constitución de 1979 no se refieren a los seminarios conciliares. No obstante, algunas de las recientes normas sobre educación como la Ley Orgánica Reguladora del Derecho a la Educación (LODE) de 1985, la Ley Orgánica de Ordenación General del Sistema Educativo (LOGSE) de 1990, la Ley Orgánica de la Participación, la Evaluación y el Gobierno de los Centros Docentes (LOPEG) de 1995, las Leyes de Calidad de la Educación (LOCE) de 2002 o la reciente LOMCE (2011), han sido objeto de declaraciones oficiales por parte de la Conferencia Episcopal Española en relación a tres aspectos fundamentales: derecho de los padres a elegir enseñanza religiosa, normativa sobre los profesores de religión católica y la asignatura de "Educación para la Ciudadanía". ${ }^{37}$

Actualmente en nuestro país, los candidatos al sacerdocio pueden realizar sus estudios de ESO y Bachillerato en cualquier institución educativa, también en los seminarios menores. Pueden acceder al

${ }^{36}$ Puelles Benítez de. M. 2000 "Política y educación. Cien años de historia" Revista de Educación: 7-36; Capitán Díaz, A. 2002 "Humanismo pedagógico en la España contemporánea" Revista Española de Pedagogía: 401-480. Cuenca Toribio, J.M. 2008. Nacionalismo, franquismo y nacionalcatolicismo: San Sebastián de los Reyes: Actas; Casas Rabasa, S. 2005. "La Storia contemporanea della Chiesa in Spagna" en Vian, G. M. (ed.), Storia del Cristianesimo, bilanci e questioni aperte, 183-187. Città del Vaticano: Atti del seminario pero il cinquantesimo del Pontificio Comitato di Scienze Storiche.

${ }^{37}$ Esta información puede consultarse en www.conferenciaepiscopal.es/. 
seminario mayor con estudios de Formación Profesional de segundo grado y gozan de los mismos derechos y obligaciones que cualquier otro estudiante de esos niveles para acceder a becas. ${ }^{38}$

\section{DE PÍO IX A PÍO XI: UN MODELO DE SEMINARIO APOLOGÉTICO}

Después de realizar una síntesis de la relación entre los gobiernos españoles, su legislación y los seminarios conciliares, pasamos a exponer concisamente la naturaleza de estos centros académicos en los documentos pontificios y conciliares del siglo $\mathrm{XX}$, sin obviar el último pontificado del siglo XIX.

Desde la fecha de publicación del Syllabus (8-12-1864) por el beato Pío IX (1846-1878), una lista 80 puntos sobre errores modernos condenados por el último papa que ejerció poder temporal en la península italiana: panteísmo, naturalismo, racionalismo, indiferentismo, socialismo, comunismo, francmasonería y distintos tipos de liberalismo y la encíclica Quanta cura, que salió de la imprenta el mismo día, la Santa Sede fue adoptando una postura de cierto repliegue sobre sí misma, una actitud apologética, con cierta prevención hacia el mundo moderno. ${ }^{39}$

Su sucesor, León XIII (1878-1903), con su indudable talla intelectual, no solo abordó en sus escritos las consecuencias del obrerismo e inauguró una larga tradición de magisterio social, sino que se preocupó de la formación de los presbíteros en dos direcciones: por una parte, con su conocida encíclica Aeterni Patris (4-8-1879) sobre la restauración de la filosofía cristiana conforme a la doctrina de Santo Tomás de Aquino y la inexistencia de conflicto entre la fe y la razón. Aunque la intención del pontífice posee una finalidad positiva: establecer en las facultades eclesiásticas «para los estudios filosóficos un método que no solo corresponda perfectamente al bien de la fe, sino que esté conforme con la misma dignidad de las ciencias humanas», se aprecia en todo el documento (que no está numerado) un regusto decimonónico y un tradicionalismo dependiente del Concilio Vaticano I, al que cita con frecuencia. En la carta encíclica se afirma, por ejemplo: «Si alguno fija la consideración en la acerbidad de nuestros tiempos, y abraza con el pensamiento la condición de las cosas que pública y privadamente se ejecutan, descubrirá sin duda la causa fecunda de los males, tanto de principios sobre las cosas divinas y humanas, emanados hace tiempo de las escuelas de los filósofos, se han introducido en todos los órdenes de

${ }^{38}$ Declaración de la Comisión Episcopal de Universidades y Seminarios de la Conferencia Episcopal Española (18-12-2009).

http://www.conferenciaepiscopal.es/index.php/comision-seminariosuniversidades/271-la-vocacion-sacerdotal-y-el-seminario.html.

${ }^{39}$ Martín Hernández, F. 1993. "La formación teológica en los seminarios españoles (1890-1925)" Anuario de Historia de la Iglesia 2: 45-96. 
la sociedad recibidos por el común sufragio de muchos. Pues siendo natural al hombre que en el obrar tenga a la razón por guía, si en algo falta la inteligencia, fácilmente cae también en lo mismo la voluntad; y así acontece que la perversidad de las opiniones, cuyo asiento está en la inteligencia, influye en las acciones humanas y las pervierte». ${ }^{40}$

El antiguo Patriarca de Venecia, luego papa san Pío X (1903-1914) hubo de enfrentarse durante su corto pontificado a la denominada crisis modernista, que era una corriente teológica tendente a aplicar los principios de la filosofía inmanentista (no la aristotélico-tomista recomendada por la Iglesia) para los estudios de teología; el resultado atisbado por el papa Sarto era la negación de algunos dogmas católicos. Su reacción fue directa y afectó a los aspirantes al sacerdocio: por el Motu proprio Sacrosanctum antistitum (1-9-1910) los presbíteros y sobre todo los profesores de ciencias sagradas debían renovar anualmente el juramento antimodernista, medida que estuvo en vigor hasta su derogación por la Sagrada Congregación de la doctrina de la fe en $1966 .^{41}$ Desde el punto vista vaticano sobre el modernismo fue expuesto en el Decreto Lamentabili y la encíclica Pascendi. Además san Pío X había escrito en un sentido más alentador la Constitución Apostólica Haerent animo, (4-8-1908) sobre la santidad de los sacerdotes.

Por otro lado, aunque no dirigido a los sacerdotes españoles, vale la pena destacar su encíclica Fin dal Principio, fechada el 8 de diciembre de 1902. Dos párrafos del documento, ilustran la concepción un tanto retraída que se esperaba de un buen sacerdote católico de inicios del siglo XX: «con el fin de preservar el clero italiano de las influencias perniciosas de los tiempos, nos parece oportuno, venerables hermanos, para recordar en esta nuestra carta, los verdaderos principios e invariable que deben regular la educación eclesiástica y todo el ministerio sagrado (...) La educación, los estudios y lo que comprende la disciplina sacerdotal siempre ha sido considerado por la Iglesia como perteneciente

40 León XIII, Enc. Aeterni Patris (4-8-1879). El documento ocupa diez folios. Este papa fue el creador de la Comisión Bíblica (30-9-1902), que en la actualidad sigue asesorando a la sede apostólica en estas materias. Todos los documentos papales que aparecen en este trabajo se han localizado en www.vatican.va, que posee unos completos elencos de los mismos. Están también publicados, en Actae Apostolicae Sedis, a partir de 1909, fecha de su creación por san Pío $X$, en formato libro; actualmente se encuentran también en formato PDF. Este mismo pontífice envió a España otra encíclica, en nada relacionada con el tema de este estudio, titulada Cum multa sint (8-12-1882) para mediar entre los católicos y los obispos ante las distintas posturas políticas de unos y otros. Cárcel Ortí, V. 2002 Historia de la Iglesia en la España Contemporánea: 115-116: Madrid, Rialp.

${ }^{41}$ Congregación para la Doctrina de la fe. 2008. Documentos 1966-2007: 35 Madrid. BAC 
totalmente a sí misma, no sólo distintas, sino totalmente independiente de las normas ordinarias de la vida secular». ${ }^{42}$

Con el papa Pío XI (1922-1939) se abandonó parcialmente ese estilo "a la defensiva" o de carácter apologético que la sede apostólica había adoptado desde la pérdida de su poder temporal y por los embates de los errores modernistas. Su predecesor, Benedicto XV (1914-1922) ya había preparado el terreno con la Carta Apostólica Maximum illud (30-111919) en la que abordó desde un talante abierto la propagación de la fe católica en el mundo entero: parecía superada la mentalidad de Pío IX, que murió considerándose un "prisionero" en el Vaticano de los unificadores de la nueva Italia. Achille Ratti dedicó dos documentos magisteriales que atañen directamente a los seminarios, la Constitución Apostólica Deus scientiarum Dominus (24-5-1931) sobre las Universidades y Facultades eclesiásticas eclesiásticas y la Carta Encíclica Ad catholici sacerdotii (20-12-1935). ${ }^{43}$

Dirigiéndose a los obispos afirma: «el seminario, por lo tanto, es y debe ser como la pupila de vuestros ojos, venerables hermanos, que compartís con Nos el formidable peso del gobierno de la Iglesia; es y debe ser el objeto principal de vuestros cuidados (...) que hagan florecer en el seminario la piedad, la pureza, la disciplina y el estudio, armando a tiempo y con prudencia los ánimos juveniles no sólo contra las tentaciones presentes, sino también contra los peligros mucho más graves a que se verán expuestos más tarde en el mundo, en medio del cual tendrán que vivir para salvar a todos». ${ }^{44}$

Solo cuatro años más tarde, el papa escribe de nuevo sobre el sacerdocio en un contexto más amplio en el que da cuenta de los seminarios cuya erección ha sido posible en todo el mundo, pero después de realizar un exhaustivo repaso de las condiciones que debe fomentar el buen sacerdote, añade «si se guardan diligentemente todas las prescripciones canónicas, si todos se atienen a las prudentes normas que, pocos años ha, hicimos Nos promulgar por la Sagrada Congregación de Sacramentos sobre esta materia se ahorrarán muchas lágrimas a la Iglesia, y al pueblo fiel muchos escándalos». ${ }^{45}$ Se puede apreciar en estas líneas una continuidad en la visión algo apologista y desgarrada del sacerdocio, aunque no le faltaran razones.

Su sucesor, Pío XII (1939-1958) tomó la pluma en 1943 para tratar sobre los estudios bíblicos de capital importancia en la pedagogía del

${ }^{42}$ León XIII, Enc. Fin dal principio (8-12-1902): 1 y 4.

43 Sobre la educación católica, Pío XI firmó la Carta Encíclica Divini illius Magistri (31-12-1939).

44 Constitución Apostólica Deus scientiarum Dominus (24-5-1931): 12.

${ }^{45}$ Pío XI, Enc. Ad catholici sacerdotii (20-12-1935): 58. 
seminario: «de este modo, las divinas Letras sean para los futuros sacerdotes de la Iglesia, por un lado fuente pura y perenne de la vida espiritual de cada uno, y por otro, alimento y fuerza del sagrado cargo de predicar que han de tomar a su cuenta. Y, a la verdad, si esto llegaren a conseguir los profesores de esta gravísima asignatura en los seminarios, persuádanse con alegría que han contribuido en sumo grado a la salud de las almas, al adelanto de la causa católica, al honor y gloria de Dios, y que han llevado a término una obra la más íntimamente unida con el ministerio apostólico». ${ }^{46}$ En la misma línea, el 12-8-1950, escribía Sobre las falsas opiniones contra los fundamentos de la doctrina cristiana y concretamente sobre el poligenismo, advirtiendo que se tuviera cuidado en los seminarios sobre esta polémica cuestión. ${ }^{47}$ Era evidente que los romanos pontífices debían dar respuesta a nuevas cuestiones, porque se planteaban incógnitas a las que la Iglesia debía responder y lo hizo hasta mitad del siglo $X X$ con los medios y lenguaje de entonces. Habría que esperar al Concilio Vaticano II para que Iglesia y cultura dialogaran de tú a tú sobre la formación sacerdotal. ${ }^{48}$

\section{EL CONCILIO VATICANO II Y SU MODELO DE SEMINARIO}

Pablo VI promulgó el Decreto Optatam totius con el apoyo de los padres conciliares el 28 de octubre de 1965. Su argumento es la formación sacerdotal. Dividido en 22 puntos, el documento cita 19 veces el término seminario. El sucesor de Juan XXIII explica que las familias cristianas son los primeros seminarios. Al referirse a los seminarios menores indica que debe existir una fluida relación entre sus directivos y los parientes de los alumnos.

Sobre los seminarios mayores, el Concilio pide a los candidatos al presbiterado que se dispongan para una dedicación plena al ministerio de la palabra y de la eucaristía, vinculando la preparación pastoral a la coordinación con profesores y a la autoridad del obispo. En cuanto a los profesores se señala que, no solo deben tener una sólida doctrina, sino también formación espiritual y experiencia pastoral para poder enseñar con una singular pedagogía. Respecto al plan de estudios, se pide que los candidatos posean idéntica preparación humanista y científica que los demás estudiantes que inician sus estudios universitarios. Se hace hincapié en el conocimiento de latín y otras lenguas de la Sagrada

${ }^{46}$ Pío XII, Enc. Divino Afflante Spiritu (30-9-1943): 32.

47 Pío XII, Enc. Humani generis (12-8-1950): 8 y 33.

48 Vergara, J. 2006. "Sapientia Christiana: tradición y modernidad en la pedagogía teológica" Anuario de Historia de la Iglesia: 69-88. El autor trata en este artículo de la evolución pedagógica en los seminarios conciliares desde la Deus scientiarum Dominus hasta la citada Constitución Apostólica de Juan Pablo II. 
Escritura para conocer también, en versión original, las obras de los Padres de la Iglesia.

Hasta aquí el documento no sorprende al lector, sin embargo, el final del Decreto está lleno de sugerencias bastante novedosas desde el punto de vista pedagógico: anima a los seminaristas a conocer además de la filosofía perenne, las investigaciones filosóficas que influyen en la época que les ha tocado vivir, especialmente en su nación; insta a saber comunicar adecuadamente lo aprendido y a conocer lo que tienen de verdadero y bueno otras religiones para poder comprender mejor la plenitud de la verdad de Cristo; promueve el diálogo con los demás, la capacidad de escuchar a todos y la utilización recta de las ciencias pedagógicas, psicológicas y sociológicas; por último alienta a favorecer el apostolado con los seglares, uno de las aportaciones más novedosas del Concilio Vaticano II. ${ }^{49}$

El 7 de octubre de 1966, la Congregación romana de Universidades y Seminarios solicitó al episcopado sugerencias para modificar los planes de estudios eclesiásticos vigentes dados por Pío XI en 1931. Las aportaciones se recogieron en cuatro volúmenes y tras su estudio, el 20 de mayo de 1968 se publicaron las Normae Quaedam ad Constitutionem Apostolicam Deus Scientiarum Dominus de Studiis Academicis Ecclesiasticis recognoscendam, con carácter experimental, pero de obligado cumplimiento. Las Normae Quaedam poseen también novedades desde el punto de vista del devenir pedagógico contemporáneo: alientan a la formación e investigación con rigor, técnicas modernas y buenos recursos; promueven una apertura a otras confesiones no católicas, no cristianas y a los no creyentes; aumentan la temporalidad de las asignaturas que se dividen en principales $u$ obligatorias y auxiliares u opcionales; se anima a mantener contactos con otras facultades eclesiásticas y civiles.

\section{JUAN PABLO II Y LOS SEMINARIOS}

Bajo el pontificado de Juan Pablo II se publicaron tres importantes documentos relativos al sacerdocio en general, a los estudios de los futuros presbíteros, que aportan también elementos sobre los seminarios. La naturaleza de los documentos es diversa: se trata de dos Exhortaciones Apostólicas y de la promulgación del Código de Derecho Canónico, cuya revisión había sido prevista por el Concilio Vaticano II.

49 Pablo VI, Decreto Optatam totius (28-10-1965). En el Decreto Presbyterorum ordinis (7-12-1965) se alude a la posibilidad de crear seminarios internacionales, diócesis peculiares o prelaturas personales, quedando a salvo los derechos del obispo del lugar. En la Encíclica Sacerdotalis coelibatus (24-6$1967)$ no hay referencias a los seminarios. 
La Exhortación Apostólica Sapientia Christiana es en realidad un antiguo documento preparado bajo el pontificado de Pablo VI en 1977, cuyo fallecimiento al año siguiente y el brevísimo pontificado de Juan Pablo I impidió publicar. ${ }^{50}$ Fue editada por Juan Pablo II con algunos retoques personales el 15 de abril de 1979. Trata sobre las Universidades y Facultades eclesiásticas: Teología, Filosofía y Derecho Canónico; está articulada en cinco capítulos iniciales y 94 artículos posteriores (con normas comunes, especiales y transitorias). Se cita el término seminario en 19 ocasiones.

Una de la principales ideas del texto es que el ministerio sacerdotal y su preparación académica está al servicio de la evangelización, para aportar ideas cristinas al mundo de hoy en la línea de Concilio Vaticano II. Los estudios, partiendo de la Sagrada Escritura y de la Tradición de la Iglesia, deben dar soluciones a los problemas que acucian al ser humano. Está clara la evolución desde la Deus scientiarum Dominus que permanecía todavía en el talante apologético de antaño, en los análisis histórico-críticos y en el silogismo. Las Normae quaedam y sobre todo la Sapientia Christiana buscan la interacción con la cultura actual, pretenden alcanzar la interdisciplinariedad y los análisis más inductivos y experimentales, quedando enterrada la pedagogía escolástica.

Juan Pablo II indica expresamente: «no hay que olvidar tampoco la gran evolución que se ha llevado a cabo en los métodos pedagógicos y didácticos, que exigen nuevos criterios en la programación de los estudios; como también la más estrecha conexión que se va notando cada vez más entre las diversas ciencias y disciplinas y el deseo de una mayor colaboración en el mundo universitario». ${ }^{51}$

Por los motivos indicados se puede afirmar que la Sapientia Christiana «es hija de la voluntad pedagógica del Concilio Vaticano II». ${ }^{52}$

El Código de Derecho Canónico fue publicado por Juan Pablo II el 25 de enero de 1983 y sustituía al de 1917. Los cánones referidos a la formación de los ministros sagrados se encuentran en el Libro II y son los números 232-264. Desde el punto de vista de las novedades pedagógicas, la ley canónica sanciona bastantes aspectos presentes en la Encíclica Optatam totius y de las Normae quaedam, es decir, la doctrina conciliar y postconciliar. En esta línea se afirma, «la formación doctrinal que ha de impartirse debe tender a que los alumnos, junto con la cultura general adecuada a las necesidades del tiempo y del lugar, adquieran un conocimiento amplio y sólido de las disciplinas sagradas,

\footnotetext{
${ }^{50}$ Vergara Ciordia, J. 2006: 78-79.

51 Juan Pablo II, Enc. Sapientia Christiana: (17-4-1979):V.

${ }^{52}$ Vergara Ciordia, J. 2006: 87.
} 
de modo que, fundando y alimentando en ellas su propia fe, puedan anunciar convenientemente la doctrina del Evangelio a los hombres de su tiempo, de manera apropiada a la mentalidad de éstos». ${ }^{53}$

Se destaca, por ejemplo, que el futuro presbítero debe formarse «diligentemente en aquello que de manera peculiar se refiere al ministerio sagrado, sobre todo en la práctica del método catequético y homilético, en el culto divino y de modo peculiar en la celebración de los sacramentos, en el trato con los hombres, también con los no católicos o no creyentes, en la administración de una parroquia y en el cumplimiento de las demás tareas». ${ }^{54}$ De este modo los alumnos del seminario se van acostumbrando a un talante abierto y de diálogo, sin traicionar la esencia de su ministerio.

También el Código recuerda la importancia del ecumenismo, las misiones y la atención a las personas más necesitadas, en los siguientes términos: «enséñense a los alumnos las necesidades de la Iglesia universal, para que se muestren solícitos en promover vocaciones, por las tareas misionales, ecuménicas y aquellas otras, también las sociales, que sean más urgentes». ${ }^{55}$ Esa apertura y magnanimidad de espíritu fomentará en los seminaristas «que se sientan interesados no sólo por la Iglesia particular a cuyo servicio se incardinen sino también por la Iglesia universal, y se hallen dispuestos a dedicarse a aquellas Iglesias particulares que se encuentren en grave necesidad». ${ }^{56}$

Por su parte, la Exhortación Apostólica Pastores Dabo Vobis, sobre la formación de los sacerdotes en las circunstancias actuales, es fruto de la VIII Asamblea Ordinaria del Sínodo de los Obispos (octubre de 1990). Fue publicada por Juan Pablo II el 25 de marzo de 1992 y se articula en 82 puntos. Se refiere a los desafíos a los que se enfrenta la formación sacerdotal, a la naturaleza y la misión del sacerdocio ministerial, la vida espiritual del sacerdote, la vocación sacerdotal dentro del trabajo pastoral de la Iglesia, la formación de los candidatos al sacerdocio en el seminario, término que cita en 72 ocasiones. En este artículo, nos referiremos únicamente al último aspecto.

Los obispos reunidos en Sínodo, en unión con el obispo de Roma, definen el seminario como lugares donde se forman pastores de almas; el seminario mayor no es solo un espacio geográfico sino una comunidad educativa promovida por el obispo, fiel a los valores evangélicos, encaminada a prolongar en la historia la misión de Jesucristo; es una

53 Juan Pablo II. 1983: Codex Iuris Canonicis (CIC): Ciudad del Vaticano: Libreria Editrice Vaticana: 248.

${ }^{54}$ Ibídem: 256.

${ }^{55}$ Ibídem: 257 § 2.

${ }^{56}$ Ibídem: 257 § 1. 
comunidad basada en la oración, los sacramentos y la caridad fraterna, pero que no descuida la formación humana, intelectual y pastoral de los futuros presbíteros con la elasticidad apropiada.

Sobre el origen de las vocaciones se alude a la familia cristiana y ante la escasez actual de seminarios menores, se aconseja que los candidatos que no procedan de ellos pasen una temporada de prueba para comprobar su posible vocación. Se aconseja a los rectores y formadores de los seminarios que conozcan la madurez y estabilidad psíquica de los candidatos de cara a realizar una libre opción por el celibato.

El seminario es una escuela de seguimiento de Jesucristo y los protagonistas de la formación sacerdotal son el obispo y toda la comunidad del seminario: alumnos y formadores (rector, director espiritual, superiores y profesores).

Todos ellos están directamente implicados en la aplicación adecuada de los nuevos planes de estudio (Ratio Fundamentalis Institutionis Sacerdotalis). ${ }^{57}$ Se aconseja vivamente que los seminaristas realicen progresivamente prácticas pastorales a la vez que estudian y exhorta a la formación permanente, sobre todo en el caso de los jóvenes sacerdotes. Estos tres últimos aspectos pueden considerarse como los más novedosos desde el punto de vista pedagógico y, en la línea con lo marcado por el Concilio Vaticano II, la consideración abierta del seminario llamado a «prolongar en la historia la misión de Jesucristo».

La Conferencia Episcopal Española, por su parte, ha publicado hace unos años un Enchiridion, recopilación de las enseñanzas eclesiales, tanto papales, como del episcopado español sobre los presbíteros y los candidatos a las órdenes sagradas desde el pontificado de Pablo VI. ${ }^{58}$

${ }^{57}$ González Lozano, 2013. F. La renovación del plan de formación de los seminarios. Del Concilio Vaticano II (1962) a Pastores dabo vobis: Madrid: UNED: 49. El primer plan de estudios aprobado data de 1970 y el segundo de 1985. No se diferencias sustancialmente.

${ }^{58}$ Conferencia Episcopal Española. Comisión Episcopal de Seminarios y Universidades. 1999 Enchiridion. Documentos de la Iglesia sobre la formación sacerdotal, (1965-1998), Madrid, EDICE: 1043-1160.

Concilio Vaticano II: Decreto Optatam totius, sobre la formación sacerdotal (28 octubre 1965).

Pablo VI: Encíclica Sacerdotalis coelibatus, sobre el celibato sacerdotal (24 junio 1967). 1979).

Juan Pablo II: Exhortación Apostólica Sapientia Christiana (15 abril 
En el caso de España, recientemente se ha renovado el acuerdo de homologación de los títulos de Diplomado, Licenciado y Doctorado cursados en los seminarios mayores, que poseen la misma validez que los realizados en cualquier universidad pública, mediante el Real Decreto 1619/2011, de 14 de noviembre, por el que se establece el nuevo régimen de equivalencias de los estudios y titulaciones de Ciencias Eclesiásticas de nivel universitario respecto de los títulos universitarios oficiales españoles, en cumplimiento de lo dispuesto en el Acuerdo entre el Estado español y la Santa Sede de 3 de enero de 1979 sobre Enseñanza y Asuntos Culturales. ${ }^{59}$

\section{CONCLUSIONES}

El devenir pedagógico de los seminarios conciliares españoles ha estado vinculado a la política religiosa de sus gobernantes hasta el Concilio Vaticano II y la transición política en nuestro país. Hubo un retraso, por parte de la Casa de Austria, por implantar las directrices tridentinas; por el contrario, los Borbones, especialmente desde el Concordato de 1753 y bajo el reinado de Carlos III, trataron de convertir los seminarios en una fuente de clérigos ilustrados, alejados del ultramontanismo jesuítico.

Los planes pedagógicos para los seminarios durante el siglo XIX oscilaron notablemente: desde el hondo marcado literario del Plan Quintana, la equiparación con los estudios universitarios con Fernando VII y la supresión de las facultades eclesiásticas en las universidades civiles bajo Isabel II. La política anticlerical de la II República condenó al ostracismo a la Iglesia católica, que recuperó terreno, aunque con una dependencia excesiva, durante el periodo del nacionalcatolicismo del

Código de Derecho Canónico, (25 enero 1983) cánones 232-264 y 10081054. Exhortación Apostólica postsinodal Pastores dabo vobis (29 marzo 1992).

Juan Pablo II a los seminaristas y presbíteros españoles: Homilía en la ordenación sacerdotal en Valencia (8 noviembre 1982); Alocución en el Seminario de Madrid (16 junio 1993); Homilía en la ordenación de presbíteros en Sevilla (12 junio 1993).

Congregación para la Educación Católica: Ratio Fundamentalis Institutionis sacerdotalis (19 marzo 1985); de la misma entidad vaticana, se recogen dieciocho documentos más de diversa índole, referidos a los candidatos a recibir las órdenes sagradas.

Conferencia Episcopal Española, La formación para el ministerio presbiteral. Plan de formación sacerdotal para los seminarios mayores (30 mayo 1996).

59 Boletín Oficial del Estado Real Decreto (14-11-2011)1619/2011. Se renuevan los anteriores acuerdos Real Decreto (13-1-1995). Boletín Oficial del Estado 3020/1995. 
General Franco. Tras la Constitución de 1979 y el último Concordato, la jerarquía católica recuperó su libertad y los obispos recuperaron protagonismo como pastores y guías de sus seminaristas. Mediante un Real Decreto de 2011 los grados de diplomado, licenciado y doctor de las Facultades eclesiásticas españolas poseen la misma validez que los otorgados por las Universidades civiles.

La actitud de los romanos pontífices desde León XIII sobre cómo debía ser el seminario desde el punto de vista pedagógico ha evolucionado considerablemente. Gioachino Pecci aportó una auténtica renovación del pensamiento tomista como instrumento para estudiar teología. Sin embargo, sus sucesores, especialmente a consecuencia de la crisis modernista, prefirieron un seminario de talante apologético y a la defensiva de los errores que produjo la aplicación de la filosofía de la inmanencia a la ciencia teológica.

Con el Concilio Vaticano II y más concretamente mediante el Decreto Optatam totius una nueva pedagogía se abre paso: en el seminario deben tenerse en cuenta otros métodos didácticos y los conocimientos útiles de la psicología y la sociología para formar al candidatos al sacerdote, que ayudado por los laicos se abre al diálogo con el mundo contemporáneo. Las Normae Quaedam de 1968 son una propuesta para un estudio más riguroso, con un plan de materias curriculares más flexible que permita además el conocimiento del diálogo ecumémico.

Juan Pablo II con la Sapientia Christiana, hija intelectual del Concilio Vaticano II, recuerda que los pilares de la teología, Sagrada Escritura y Tradición, deben plantearse en interacción con la cultura actual. En la Pastores dabo vobis expone ampliamente las características de un seminario contemporáneo.

En definitiva, es posible afirmar que la separación Iglesia-Estado manteniendo unas correctas relaciones concordatarias, ha sido el modo de terminar con la secular alianza entre el trono y el altar y sus no deseables consecuencias. También la evolución del pensamiento papal y conciliar sobre la pedagogía en el seminario, desde la postura apologética y defensiva a la abierta a la cultura y la problemática del mundo en el que vivimos, puede calificarse de sumamente positiva. 


\section{BIBLIOGRAFÍA}

Andrés-Gallego, J.-Pazos, A.M. 1999. La Iglesia en la España contemporánea/1: 1800-1936: Madrid: Encuentro.

Andrés Martín, M. 1976. La supresión de las facultades de teología en las Universidades españolas: (1845-1855): Burgos: Aldecoa Ediciones.

Andrés Martín, M. 1980. "Facultades de teología, planes de estudio y proyecto de hombre" Scripta Theologica 12: 161-169.

Barreiro, X.R. 2003. Historia de la Universidad de Santiago de Compostela: vol. II El siglo XIX. Publicaciones de la Universidad de Santiago: 46: Santiago de Compostela.

Boletín Oficial del Estado, Reales Decretos (13-1-1995) 3020/1995 y (14-11-2011) 1619/2011.

Capitán Díaz, A. 1991. Historia de la Educación: vol I. De los orígenes al Reglamento General de Instrucción Pública. vol.Il Pedagogía Contemporánea Madrid: Dykynson.

Capitán Díaz, A. 2002 "Humanismo pedagógico en la España contemporánea" Revista Española de Pedagogía: 223: 401-480.

Cárcel Ortí, V. 1981. "Decadencia de los estudios eclesiásticos en la España del siglo XIX" Hispania Sacra 33: 19-32.

Cárcel Ortí, V. 1990 "Estado material, académico y moral de los seminarios españoles durante el siglo XIX" Seminarios 77-78: 267-275.

Casas Rabasa, S. 2005. "La Storia contemporanea della Chiesa in Spagna" en Vian, G. M. (ed.), Storia del Cristianesimo, bilanci e questioni aperte, 183-187. Città del Vaticano: Atti del seminario pero il cinquantesimo del Pontificio Comitato di Scienze Storiche.

Conferencia Episcopal Española. Comisión Episcopal de Seminarios y Universidades. 1999. Enchiridion. Documentos de la Iglesia sobre la formación sacerdotal, (1965-1998), Madrid, EDICE.

Congregación para la Doctrina de la fe. 2008. Documentos 19662007: 35: Madrid. BAC. 
Congregación de Universidades y Seminarios, Normae Quaedam ad Constitutionem Apostolicam Deus Scientiarum Dominus de Studiis Academicis Ecclesiasticis recognoscendam (20-5-1968).

Cuenca Toribio, J.M. 2008. Nacionalismo, franquismo y nacionalcatolicismo: San Sebastián de los Reyes: Actas.

Díaz Sánchez-Cid, J. R. 1991. El seminario conciliar de San Ildefonso de Toledo: cien años de historia (1889-1999): Toledo: Instituto Teológico San Ildefonso.

Espino Martín, J. 2003. "Política y enseñanza del latín: conservadores y liberales en la enseñanza de la gramática latina durante el reinado de Fernando VII". Estudios Clásicos 123: 45-65.

Feijoo, B. J. 1736. Teatro crítico universal. Discurso 11. Introducción. Publicado por Proyecto de Filosofía en español: www.filosofia.org.

Fernández Collado, A. 1991: Historia de la Iglesia en España. Edad Moderna: Toledo:

Instituto Teológico San Ildefonso.

García Castro, M. D.-Mediano Benito, J.M. 1998: "La legislación universitaria en España y América durante los primeros Borbones": Revista de Estudios de historia social y económica de América: 16/17: 192-195.

García Fraile, J.A. 1996. "La educación en los Textos Constitucionales españoles":148-153 en Berrio, J. (ed.) La educación en España. Textos y documentos: Madrid: Actas.

García Navarro, J.J. 1992: El origen histórico español de las facultades eclesiásticas y la legislación eclesiástica desde la Constitución Deus Scientiarum Dominus a la Sapientia Christiana: Tesis doctoral inédita, Universidad de Navarra.

Greyerz, K. von. 2000: Religion und Kultur. Europa 1500-1800: Göttingen:Vandenhoeck und Ruprecht Verlag.

Gil, E. (S.I.) 1993: La Universidad Pontificia de Comillas: cien años de historia 1892-1992: Santander, Universidad Pontifica Comillas.

Gil Fernández, L. 1997. Panorama social del humanismo español: 435-457 Madrid: Tecnos. 
González Lozano, F. 2013: La renovación del plan de formación de los seminarios. Del Concilio Vaticano Il (1962) a la Pastores dabo vobis (1992): Madrid: UNED.

Gonzalo, R. 1993. Historia de la Iglesia en España (1931-1936) La Segunda República: 1931-1936: Historia de la Iglesia en España. La Guerra Civil (1936-1939): Madrid: Rialp.

Izquierdo, C. 2001: "La reforma de los estudios eclesiásticos": Anuario de Historia de la Iglesia 10: 207-213.

Juan Pablo II, 1983: Codex Iuris Canonicis (CIC): Ciudad del Vaticano: Libreria Editrice Vaticana.

Juan Pablo II, Enc. Sapientia Christiana: (17-4-1979)

Juan Pablo II, Exhort. Postsinodal Pastores dabo vobis (29-31992).

Laboa Gallego, J.M. 1981: Iglesia y religión en las Constituciones españolas: Madrid: Encuentro.

León XIII, 1879: Enc. Aeterni Patris (4-8-1879).

León XIII, 1882: Enc. Cum multa sint (8-12-1882).

León XIII, 1902: Enc. Fin dal principio (8-12-1902).

Macanaz, M. de, 1841. Pedimento número 39 del fiscal general Don Melchor de Macanaz sobre abusos de la Dataría; provisión de beneficios; pensiones; coadjutorias; dispensas matrimoniales, espolios $i$ vacantes; sobre el Nuncio; derechos de los Tribunales eclesiásticos; juicios posesorios y otros asuntos gravísimos. Imprenta Nacional: La Coruña: 47-48.

Martín Riego, M. 1994. La formación del clero. El seminario conciliar de Sevilla (1831-1931): Caja Rural de Sevilla: Sevilla.

Martín Hernández, F. 1993. "La formación teológica en los seminarios españoles (1890-1925)" Anuario de Historia de la Iglesia 2: 45-96.

Martínez Herrer, C. 2014. "Santo Tomás de Villanueva O.S.A. y los Colegios jesuitas de Gandía y Valencia. Cuestiones histórico-educativas" 
Actas del VII Congreso Internacional Educación Católica para el siglo XXI: Universidad Católica san Vicente mártir de Valencia: 287.

Martínez Ruiz, E. 1998. Diccionario de Historia Moderna de España: 208 Madrid: Akal.

Más Galván, C. 1981. Jansenismo y regalismo en el seminario de san Fulgencio de Murcia: Alicante. Universidad de Alicante.

Ministerio de Educación y Cultura. 1979-1982: Historia de la Educación en España:

De los inicios a las Cortes de Cádiz. De las Cortes de Cádiz a la Revolución de 1868. De la Restauración a la II República. 3 vols. Madrid. MEC.

Ministerio de Educación Cultura y Deporte. 2004: El Sistema Educativo español. Madrid: MECD/CIDE.

Molina González, J.R: 2012 "La evolución de la formación sacerdotal en el Seminario Conciliar de Pamplona entre 1831 y 1978" Príncipe de Viana 255: 287-312.

Negrín Fajardo, O. 2004. Historia de la Educación en España. Autores. Textos y documentos: Madrid: UNED.

Negrín Fajardo, O. (ed.) 2006. Historia de la Educación española: Madrid: UNED.

Nuñez Rivero, C. 2011: La Iglesia católica y el Estado constitucional. El caso español: Madrid: Endymon S.L.

Pablo VI, Decreto Optatam totius (28-10-1965).

Pablo VI, Decreto Presbyterorum ordinis (7-12-1965). Ariel.

Palacio Atard, V. 2006. Carlos III, el rey de los ilustrados: Madrid:

Payne, S.G. 1984. Spanish Catholicism: An Historical Overview, Madison: University of Wisconsin Press.

Pérez Mier, L. 1947. "El Convenio español sobre seminarios y universidades de estudios eclesiásticos" Revista Española de Derecho Canónico 2: 87-152. 
Piñero, J.M. 1979. "La dotación de la Iglesia por el Estado en los nuevos acuerdos entre la Santa Sede y España". Ius Canonicum 19:303328.

Pío IX, Syllabus (8-12-1964).

Pío IX, Enc. Quanta cura (8-12-1864).

Pío XI, Constitución Apostólica Deus scientiarum Dominus (24-51931).

Pío XI, Enc. Divini illius Magistri (31-12-1939).

Pío XI, Enc. Ad catholici sacerdotii (20-12-1935).

Pío XII, Enc. Divino Afflante Spiritu (30-9-1943).

Pío XII, Enc. Humani generis (12-8-1950).

Puelles Benítez de, M. 1991 "El sistema educativo republicano: un proyecto frustrado" Historia Contemporánea 6: 159-171.

Puelles Benítez de, M. 2000 "Política y educación. Cien años de historia" Revista de Educación: 7-36

Redondo, E.-Vergara, J. 1993. "La secularización docente (17761845)" Perspectiva Educacional 21/22: 17-25.

Rodríguez San Pedro, L.E.-Polo Rodríguez. 2010. Universidades hispánicas: colegios y conventos universitarios en la Edad Moderna II: Salamanca: Universidad de Salamanca.

Suárez, F. 1988. La crisis política del Antiguo Régimen en España (1800-1840): Madrid: Rialp.

Tomás y Valiente, F. 1989. El marco político de la desamortización: Madrid: Ariel.

Vergara Ciordia, J. (ed.) 1997. Estudios sobre la secularización docente en España: Madrid: UNED.

Vergara Ciordia, J. 2004. Historia y pedagogía del seminario conciliar en Hispanoamérica (1563-1800): Madrid: Dykynson.

Vergara Ciordia, J. 1987. "El regalismo jansenista, los obispos ilustrados y San Carlos Borromeno, factores de configuración de los 
seminarios en el siglo XVIII". Revista Española de Pedagogía 176: 239252.

Vergara Ciordia, J. 2005. "Datos y fuentes para el estudio de los seminarios conciliares en Hispanoamérica". Anuario de Historia de la Iglesia 14: 239-300.

Vergara Ciordia, J. 2006. "Sapientia Christiana: tradición y modernidad en la pedagogía teológica" Anuario de Historia de la Iglesia 15: $69-88$.

\section{WEBGRAFÍA}

www.congreso.es.historia.constituciones/. Consulta de las Constituciones españolas.

www.conferenciaepiscopal.es/ .

Declaración de la Comisión Episcopal de Universidades y Seminarios de la Conferencia Episcopal Española (18-12-2009). www.conferenciaepiscopal.es/index.php/comision-seminariosuniversidades/271-la-vocacion-sacerdotal-y-el-seminario.html.

www.filosofia.org/. En esta página web se han consultado las leyes educativas del siglo XIX. 